\title{
Metal Element Doping Graphene for the Oxygen Electrode: A Density Functional Calculation
}

\author{
L. Q. Cai ${ }^{1}, H Z h u^{1, *}, Y e \operatorname{Liu}^{2}$, Z. Y. Jiang ${ }^{2}$, H. Y. Liu', Z. D. Yu ${ }^{1}$ \\ ${ }^{1}$ School of Energy and Power Engineering, Jiangsu University of Science and \\ Technology, Zhenjiang 212003, China \\ ${ }^{2}$ Bohai Shipyard Group Co. Ltd, Huludao 125003, China \\ *E-mail: zhjust16@163.com
}

doi: $10.20964 / 2019.01 .47$

Received: 8 September 2018 / Accepted: 24 October 2018 / Published: 30 November 2018

As the fundamental electrochemical reactions, the sluggish kinetics of the oxygen reduction reaction (ORR) and oxygen evolution reaction (OER) limit the commercialization of the renewable fuel cells. Alternative to the commercial precious metal catalysts, the development of inexpensive and efficient dual-functional catalysts is of prominent importance. Herein, based on the density functional theory calculation, the ORR/OER activity of the functional graphene is systematically investigated where the $3 d$ transition metal elements ( $\mathrm{Sc}, \mathrm{Ti}, \mathrm{V}, \mathrm{Cr}, \mathrm{Mn}, \mathrm{Fe}, \mathrm{Co}, \mathrm{Ni}, \mathrm{Cu}$ and $\mathrm{Zn}$ ) are selected as the doping components, aiming to screen out the efficient candidates for the oxygen electrocatalysis.

Keywords: Oxygen electrod, $3 d-$ TM doped graphene, Fuel cells, DFT

\section{$\underline{\text { FULL TEXT }}$}

(C) 2019 The Authors. Published by ESG (www.electrochemsci.org). This article is an open access article distributed under the terms and conditions of the Creative Commons Attribution license (http://creativecommons.org/licenses/by/4.0/). 